\title{
THE REFORM OF PUBLIC FINANCE IN THE CZECH REPUBLIC
}

\section{Introduction}

Act no. 261/2007 Coll., on the stabilization of public budgets was passed last year. This act came into effect on $1^{\text {st }}$ January 2008. The Act on the Stabilization of Public Budgets is the group of legal rules which are concerned with taxes including environmental taxes, social area (especially state social support, living and subsistence minimum, system of sickness insurance, wages of state employees and employment) and with the area of public health insurance and the activities of health insurance companies.

The aim of the Act on the Stabilization of Public Budgets is to optimize state budget revenues and expenditures, to sustain the economic growth of the Czech Republic and to protect the environment. The main aim of this act in the area of the state budget expenditures is to stop any increase in state spending, because the volume of expenditure from the state budget is not sustainable. The Act on The Stabilization of Public Budgets was passed as the reform act which deals with public finance in the Czech Republic.

The regulation on the stabilization of public budgets is designated as a tax reform, a reform of financing health service, a reform of pension insurance and budgetary reform. What does the word "a reform" mean? It is important to be aware that not all the changes concerning financing the system can be called "a reform". A reform is always a fundamental, systemic change to the whole system. The concept of "reform" is not a legal definition; this concept is not defined by any law or statute. Encyclopaedias define the word "reform" as a fundamental modification, change, transformation or reformation. Usually, a reform is bound to a reaction to economic, social and political changes, and the aim of reform is to adjust the legal regulations to these new conditions. The reform aims to guarantee economic growth and fairness in taxation. It is difficult to observe whether it is a reform or an 
amendment, because the difference between reform and a particular change is not clear. The reform of public finance is not a simple process, because the preparation of this reform may take a few years. In this period, lots of particular amendments are passed, and afterwards new legal regulations of the system are codified, and this codification terminates the process of reform.

Reforms in the area of financing public need are not the invention of $20^{\text {th }}$ century. The reforms which were made during the reign of the Empress Maria Theresia can be considered to be the beginning of the financial reforms, in the modern sense, for the territory of the Czech Republic. She needed to increase the state finances which had been drained by war. The Empress created some central public economic bodies, established new taxes, fees, customs and stimulated completion of the state revenues and expenditures. The summary of revenues and expenditures could be considered to be the same as the basic state budget.

A lot of problems needed to be solved after the creation of the Czechoslovak Republic in 1918, including the public finance system. Subsequently, legal rules were passed with the aim of consolidating public finance, e.g. in 1927, so-called financial amendments were passed. Those amendments changed the local authorities' financial system. In addition, the act on direct taxes was passed. A lot of these important changes were the output of a reforming initiative by Professor Karel Engliš, then the Minister of Finance. That system of the creation of and content of the public budget, adopted in 1927, continued until 1947.

After 1948, in the context of political changes, there was the change to the content of the financial system (e.g. national insurance, which was managed using the principal of fund management, was included into the state budget in 1950). At the beginning of the 1960s, the tax system was modified, and the whole area of financial law was influenced by creation of federation.

Obviously, the next period of important changes occurred after 1989. Apart from the important political changes, the amendments of legal regulation, as a result of the new political environment, were adopted. A lot of new acts and by-laws were passed. These laws and by-laws regulated the new social relationships established by a new political situation (e. g. new tax acts were passed). These new tax acts are called "the new tax system of 1993".

In 2004 the Czech Republic joined the European Union. This fact resulted in changes to many legal rules, including the financial legal rules to match the rules of other European Union member states. Apart from those processes between the Czech Republic and the European Union, some changes in Czech society took place and are still occurring today. It is necessary to fulfil the needs of the state, to solve demographic problems (e.g. the ageing of the population of the Czech Republic) as well as to improve living conditions. Due to the increasing deficit in public finances, 
the government prepared amendments to many acts, which are known as the "Act on the Stabilization of Public Budgets". Although this act is called a reform of public finance, the regulations only change some legal rules aiming at responding to social changes, ensure a decrease in the budgetary deficit, and fulfil the criteria for convergence in the European Union. These legal rules, which are amended by the Act on the stabilization of public budgets, are the rules on taxes, welfare systems and public health insurance. The aim of the Act on the stabilization of public budgets is to optimize the revenue of the state budget, to support economic growth, to empower environmental protection and to stop the increase of public budget expenditure. The public debt and the deficit of the state budget are very high. This is a very serious problem for both the economy and for the state.

One of the reasons for the increase of public debt is that in the Czech Republic there is an increase in welfare expenditure. Those expenditures grew by more than $70 \%$ since 1999, and in 2007 were CZK 70 billion higher than in 2006. According to the Program Declaration, the government has decided to decrease the deficit in the government sector in 2008 to a corresponding level of $3 \%$ of gross domestic product, and in 2009 to the level of $2.6 \%$ of gross domestic product, and again in 2010 to the level of $2.3 \%$ of gross domestic product. The current mandatory expenditures should be revised so that their share of the state budget falls below $50 \%$ by 2010 . The government will fulfil the Czech Republic's obligation to European Union in the area of fiscal strategy, with the aim of preparing the Czech Republic for admission to the Euro. Every year this fiscal strategy is included in the Convergence Programme. In 2004, the government of the Czech Republic committed itself to decrease the deficit in public finances in this way, so that by 2008 a transparent and sustainable fulfilment of the Maastricht Convergent Criteria of fiscal sustainability will be achieved. The Czech Republic committed itself to the rate of fiscal consolidation, which will provide $1 \%$ growth by 2012 - the medium-term fiscal aim as defined by the Pact of Stability. It may be concluded from the state budget and the budgetary plan for 2008 and 2009 that the 2004 strategy of fiscal consolidation will not be fulfilled due to the increase in welfare payments. Diverting from this strategy will surely incur a negative assessment of the Czech Republic by the European Commission, which would include giving notice for the procedure of excessive deficit to the Council ECOFIN $^{1}$ (releasing a new appeal for the elimination of an excessive deficit and other recommendations). A withdrawal of Cohesion Fund support (for the Czech Republic it could amount to $€ 1.4$ billion per year) could be the sanction for not keeping the deficit within the recommended limits. 


\section{Main changes in the tax area}

In the tax section of the Act on the Stabilization of Public Budgets, the Programme declaration of the Government of the Czech Republic is set in stone. The changes have influenced practically all tax acts and can be divided into three main groups, namely reform changes, harmonization changes and technical changes.

\section{1) Indirect taxes}

Value-added tax, excise taxes and new environmental taxes are classified as the group of indirect taxes in the Czech Republic.

The area of value added tax is harmonized within the European Union; therefore, a lot of regulations on value added tax come from the EU. The Act on value-added tax is mainly conforms to acquis communautaire. The Czech Republic acquired two exemptions which deal with the amount of the turnover for compulsory registration of value added tax (value added tax registration of the person is mandatory if their turnover reaches CZK 1,000,000 per 12 months); in addition, there is a reduced rate on heating and home construction including reconstruction and modernization. The main changes to reforms in the area of value added tax are, with effect from $1^{\text {st }}$ January 2009, a group of related companies can be registered as a single value added tax entity, and a reduced rate of value added tax on social housing constructions has been introduced. The reduced rate of value added tax increased from 5\% to $9 \%$; a reduced rate applies to food supply, medicine, newspapers etc.

In the area of excise taxes, the rates of tax increased on tobacco products. These rates are now fully compatible with the rules of the European Union. Taxation on gas was excluded from the regulation on excise taxes, and a new natural gas tax has been introduced. Other changes to value added tax and excise taxes were more technical than reformatory.

The Act on the Stabilization of Public Budgets introduced a new type of indirect tax, implementing the relevant European Union regulations in the area of environmental taxes. Since the $1^{\text {st }}$ January 2008 three environmental taxes have been levied in the Czech Republic, namely a natural gas tax, an electricity tax and a solid fuel tax. These indirect taxes are supposed to improve environmental protection.

\section{2) Direct taxes}

The following taxes are classified as direct taxes in the Czech Republic: personal income tax, corporate income tax, real-estate tax, road tax, gift tax, inheritance tax and real-estate transfer tax. Personal income tax and corporate income tax are the 
two main direct taxes in the Czech Republic. The tax yield of these income taxes is divided between the state budget and budgets of regions and local authorities.

The reform part of the changes to personal income tax is typical of introducing a flat rate of tax and other related changes. The flat rate of tax substituted the progressive sliding-scale tax rate with four tax brackets. On the basis of economic analysis, the Ministry of Finance decided on a flat rate of tax at $15 \%$. Thus the rate of personal income tax is now $15 \%$ and in 2009 is set to decrease to $12.5 \%$, but this decrease can be changed up to the end of the year 2008. The tax rate decrease was compensated by an increase in the tax threshold of personal income tax. The employee's taxable income (the tax threshold of employment income) was extended by employee's statutory health insurance and social security contributions paid by the employer. The tax threshold of employees is called the "super-gross salary". The payments of health insurance and social security contributions are now not tax deductible items, which can decrease the tax threshold of business incomes.

On the other hand, the tax credits, which are binding to the taxpayer, were increased. This increase was made to compensate for the disadvantage to low-income taxpayers, who were taxed in the lowest tax bracket at $12 \%$. The tax burden of these taxpayers is now no worse than their tax burden before the reform. Of significance is the increasing of the tax credit for a husband or wife (dependent spouse tax credit). This increased dependent spouse tax credit compensates for the abolishing of the married couples' joint taxable threshold. Some tax exemptions were cancelled.

The rate of corporate tax continues to successively decrease. The rate is now $21 \%$, and will decrease to $20 \%$ in 2009 and to $19 \%$ by 2010 . The decrease rate of corporate tax is compensated for by the raising of the corporate tax threshold.

Real estate tax is payable by the owner of land or buildings situated in the Czech Republic. The revenues from real estate tax constitute the revenue for the local authorities. Real estate tax comprises of two taxes, namely land tax and building tax. The most important change to real estate tax is the authorization of local authorities to introduce a local coefficient. The local coefficient may vary from 2 to 5 and this coefficient is multiplied by the real estate tax. Local authorities can increase their budgetary revenues. Local authorities can also now exempt owners of agricultural land from paying real estate tax.

The transfers of property are taxed by transfer taxes, namely gift tax, inheritance tax and real-estate transfer tax. The yield of these taxes flows into the state budget. The main change in the area of transfer taxes is the extension of exemptions to gift tax and inheritance tax. Since 2008 direct relatives and spouses and other relatives (in the collateral line) have been exempted from paying gift tax and inheritance tax. 


\section{3) Tax procedure}

The changes which are bound to the reform of public finance not only amended material tax law, but also the process of tax administration. The Act on Administration of Taxes and Fees was changed especially with reference to binding decisions by the tax administrator, the recording of taxpayers' duties on given or received monies, interests on late payments and confidentiality.

The institution of binding decisions was extended. The purpose of the regulation is to avoid incorrect tax payment procedure. A taxpayer is entitled to apply for a binding decision at the tax administrator or the Ministry of Finance. The binding decisions deal, for example, with transfer pricing, value added tax rates or tax deductible items. The administration fees have to be paid for the application for binding decisions. The binding decisions should be followed by legal entities and businesses.

\section{Main changes to the areas of social security and health care}

The concept of social security is mostly connected with the welfare system. In the Czech Republic social security comprises of health insurance, pension insurance, the system of state benefits and social care (social services). Health insurance and pension insurance is bound into the payment of premiums. Social security is the part of state social policy. This security is used to solve the effects of social upheaval or risks and act as a guarantee for social stability.

In the free market economy, these principles of social security respect: universality, equality, entirety, subsistence, social stability, social solidarity, social justice and participation.

The financing of social security is closely tied to the system of public budgets, respectively on public revenues and public expenditures. Direct instruments (obligatory payments, allowances) and indirect instruments (tax relief) are used to finance social security. In the Czech Republic, the expenditure on social security (and state policy of employment) is derived from the state budget. Also social security payments are established as state revenue. This revenue has a specific character in contrast to other revenue (e. g. taxes or fees).

The financing of social security becomes a serious problem in most countries due to the insufficiency of public resources to finance public needs (decrease of public revenue) and the increase of citizens' public needs. States have to decide how to replace the current system of continuously financing social security from the state budget. Financing the system through the extra-budgetary fiscal fund of social security supplements with the other forms of financing - private insurance 
- is one way to replace the current system. Most countries prefer a combination of the continual financing of the social security system (a pay-as-you-go system; an unfunded system in which current contributors to the system pay the expenses for the current recipients) and financing from capitalized funds. This is called a multi-pillar system with the payment of premiums by beneficiaries, employers and the state. It can be two- or three-pillar system, when as well as the public pillar, a voluntarily private pillar or obligatory private pillar exists. In the Czech Republic, the twopillar system is used, but in a narrow scope, since the voluntary insurance is not very important. The basis of the system rests on the continuous financing system and most of the money is spent from the state budget.

The reform of public finance brought amendments to many acts in the social system area (e.g. Act of State Social Support, Act on Living on the Subsistence Minimum, Act on Sickness Insurance or Act on Pension Insurance). These changes are called the "first stage of the social reforms". The second and the third stage of social reforms should comprise of, for instance, the introduction of a 'negative' tax, which replaces some social contributions along with changes in administration etc.

With reference to pension insurance, the proposal to amend the Act on Pension Insurance is in the legislative process. This amendment is called "first stage of the reform of pension insurance". The main principle of this amendment is to change the conditions for receiving old-age pension. The retirement age for men and women with at least one child will increase from 63 years to 65 years, and the retirement age for women with two or more children will increase from 62 to 64 years. The duration of pension insurance, which is necessary to qualify for a pension, will increase from at least 25 years to at least 35 years. Within the second and third stage of the reform of pension insurance, the problem of financing this system should be solved with the emphasis on the relationship between public pension insurance and private pension insurance.

In the Czech Republic, health insurance is not the part of the social security system, although it is common in many countries. The main aim of health insurance is to ensure health care without direct payment by the natural person. Everyone needs such health care. The payment for health care is provided by health insurance companies to the health care institutions. The natural person does not pay directly for the health care, but this payment is paid in the form of premiums to the health insurance. The insurance principle is strictly adhered to in the case of health insurance. This means that the insurance is individually based (everyone is insured, everyone has their own insurance). The employer participates in the payment together with the employee. The state pays the premiums for some people (e.g. students, the elderly) and some people, like business owners, pay the premiums in full. 
Health insurance forms the revenue of a special fund managed by the health insurance companies. Health insurance is an obligatory payment, which is not revenue destined for the state budget, but the revenue of the General Health Insurance Company of the Czech Republic, or other health insurance companies that are public bodies (legal entities sui generis). The budgets of health insurance companies are granted from the state budget for those people (children, the elderly) for whom the health insurance premiums are paid for by the state.

The Act on the Stabilization of Public Budgets amends many acts in the area of public health insurance (e.g. the Act on Public Health Insurance, the Act on the Public Health Insurance Premium and the act regulating health insurance companies). The main change is the introduction of regular payments for visiting health care institutions, for residence in hospitals or for items on prescription. The Czech Constitutional Court has declared that this regulation conforms with the Constitution. The reform should continue with legal transformation of hospitals and other changes. The health reforms are the subject of many political and scientific discussions and are not universally accepted. 


\section{Streszczenie}

Reforma finansów publicznych w Republice Czeskiej została wprowadzona ustawą o stabilizacji budżetów publicznych. Pomimo, że akt ten zawiera wiele istotnych zmian można mieć wątpliwości czy uprawnionym jest nazwanie go „reformą"? Reforma stanowi zawsze fundamentalną, systematyczną modyfikację całego systemu. Wprowadzone zmiany w finansach publicznych nie spełniają warunków reformy. Celem wspomnianej ustawy było, jak to ujęto w tytule, ustabilizowanie dochodów i wydatków publicznych. Stabilizacja nie może być określana jako „reforma".

Efekty zmian w wyniku wprowadzenia ustawy o stabilizacji budżetów publicznych będą znane w swoim czasie, jednakże proces ten powinien być kontynuowany na innych płaszczyznach, np. w zakresie ubezpieczeń społecznych i zdrowotnych. 